\title{
Methodological choices for research in Information Science: Contributions to domain analysis ${ }^{1}$
}

\author{
Opções metodológicas em pesquisas na \\ Ciência da Informação: contribuições \\ a uma análise de domínio
}

\author{
Juliana Lazzarotto FREITAS² \\ Leilah Santiago BUFREM ${ }^{2}$ \\ Sônia Maria BREDA ${ }^{3}$
}

\begin{abstract}
The article focuses on the ways of organizing studies according to their methodological choices in the Base Referencial de Artigos de Periódicos em Ciência da Informação (Reference Database of Journal articles in Information Science). We highlight how the organization of scientific production by the methodological choices in Information Science contributes to the identification of its production features and domain analysis. We studied research categories and proposed five classification criteria: research purposes, approaches, focus, techniques and type of analysis. The proposal of a corpus in Information Science is empirically applied, represented by 689 articles, 10\% of the production indexed in Base Referencial de Artigos de Periódicos em Ciência da Informação from 1972 to 2010. We adopt content analysis to interpret the methodological choices of authors identified in the corpus. The results point out that exploratory studies are more predominant when considering the research purpose; regarding the research approach, bibliographic and documentary studies are more predominant; systematic observation, questionnaire and interview were the most widely used techniques; document analysis and content analysis are the most widely used types of analysis; the research focus of theoretical, historical and bibliometric studies are more predominant. We found that some studies use two methodological choices and explicit epistemological approaches, such as the studies following the positivist approach in the 1970s, and those influenced by the phenomenological approach in the 1980s, which increased the use of methods in qualitative research.
\end{abstract}

Keywords: Brapci. Database. Information Science. Methodological choices. Scientific methodology.

\section{Resumo}

Estudo sobre modos de organização de pesquisas por opções metodológicas. Objetiva evidenciar como a organização da produção científica por opções metodológicas na área de Ciência da Informação contribui para identificação de características de produção e realização de análises de domínio. Estuda categorias de pesquisa e propõe uma classificação consoante cinco critérios: fins, meios, enfoques, técnicas utilizadas e análises realizadas. Aplica empiricamente a proposta em um corpus do domínio da Ciência da Informação, representado por 689 artigos, 10\% da produção de artigos indexados na Base de Dados Referenciais de Artigos de Periódicos em

\footnotetext{
1 Article based on the dissertation J.L. FREITAS, entitled "Opções metodológicas em pesquisas na área de Ciência da Informação: contribuições a uma análise de domínio", Universidade Federal do Paraná, 2012

2 Universidade Estadual Paulista Júlio de Mesquita Filho, Faculdade de Filosofia e Ciências, Programa de Pós-Graduação em Ciência da Informação. R. Hygino Muzzi Filho, 737. Mirante, 17525-000, Marília,SP, Brasil. Correspondence to/Correspondência para:J.L.FREITAS. E-mail:<julilazzarotto@gmail.com>.

3 Universidade Federal do Paraná, Setor de Ciências Sociais Aplicadas, Departamento de Ciência e Gestão da Informação. Curitiba, PR, Brasil. Received in 2/20/2014, resubmitted on 10/9/2015 and approved in 1/13/2015.
} 
Ciência da Informação de 1972 a 2010. Utiliza análise de conteúdo para identificar as opções metodológicas dos autores no corpus selecionado. Conclui que: na pesquisa quanto aos fins, relativa ao seu grau de profundidade, há predominância dos estudos exploratórios; na pesquisa quanto aos meios, pesquisas bibliográfica e documental apresentam maior grau de incidência; observação sistemática, questionário e entrevista são as técnicas preferencialmente utilizadas; análise documental e de conteúdo são as análises mais recorrentes; sobressaem pesquisas dos enfoques teórico, histórico e bibliométrico. Observa ocorrência de conjunção do uso de opções metodológicas e explicitação das correntes epistemológicas, como estudos afinados ao positivismo na década de 1970 e, na década seguinte, influência da fenomenologia, que ampliou o uso de métodos nas pesquisas qualitativas.

Palavras-chave: Brapci. Base de dados. Ciência da Informação. Opções metodológicas. Metodologia científica.

\section{Introduction}

The study used the organizational model of methodological choices proposed by Freitas (2012) to analyze the scientific production in Information Science. The framework of the study considers that the methodological choices or structures for writing scientific papers derive from epistemological and theoretical approaches that accept and validate a scientific domain. Therefore, as a theoretical assumption, Bruyne et al. (1977) four-pole model of methodological practice was used to understand scientific research practices whose structure follows the convergence of four poles of research, hence denominated as dimensions. We used the Base Referencial de Artigos de Periódicos em Ciência da Informação (Brapci, Reference Database of Journal articles in Information Science) to apply and validate the model, as it is the most complete repository of scientific literature in the field of Information Science in Brazil.

Without the intention of making research formats rigid, the categories we propose are based on a four-pole model and theoretical frameworks as well as previous attempts to rate studies for their methodological choices. The categories of organization are based on five classification choices: the purpose, approach, focus, technique and analysis of research studies. existing classification systems, although we are in agreement with Lloyd (1995, p.150, our translation) that "science is not a discourse that pretends or achieves absolute objectivity, but a set of socially constructed practices in an attempt to gradually discover the causal structure of reality"4.

\section{Theoretical research framework}

Regarding the methodological developments of research in Information Science, González de Gómez (2000) states that the definition of methodological strategies regarding the epistemological and political domains welcome and legitimate the conditions for the production of research objects. With the proposal to clarify or scientifically analyze a domain from a theoretical or empirical point of view, the analysis of scientific journals allows an understanding of the history of intellectual production and research methodological approaches. With regard to the domain, according to Lloyd (1995, p.25, our translation), scientific journals are a resource to build theoretical objects of investigation, as well as "to add and do justice to the history of science in the accumulation of knowledge"

Categorization as a way to systematize and organize information and knowledge is a guideline not only to standardize information systems, databases and libraries, but to facilitate the development of scientific production in a field with domain analysis, covering metric studies, as well as user's information retrieval. Although the areas of knowledge have endeavored in classifying studies according to their methodological principles, the tendency to adopt a formal standard of presentation of academic and scientific papers remains.

\footnotetext{
4 "a ciência não é um discurso que pretenda ou atinja a objetividade absoluta, mas um conjunto de práticas socialmente construídas na tentativa de descobrir progressivamente as estruturas causais da realidade".

5 "para incorporar efazer justiça à história da ciência em sua acumulação de conhecimento".
} 
In opposition to this trend, we selected manifestations of scientific thought in the field that are considered as previous attempts toward the object of this research, beginning with the study of Cunha (1983) who surveyed the most widely used techniques for the studies of users and defined them, pointed out their characteristics, advantages and disadvantages.

The study of Feehan et al. (1987) reports a project whose objective was to analyze aspects and trends of research in library economy and Information Science by selecting all representative articles in the field, choosing a random sample for the study. We classified the articles according to the topic and research method, the types of libraries studied, and the analytical techniques used. The classification of the research methods included Bibliometrics, Content Analysis, Delphi Method, Experimental Study, Historical Research, Observation and Description, Operational Research, Secondary Analysis, Survey, among others.

Järvelin and Vakkari (1993) confirm, through content analysis, that in recent decades the literature in library economy and IS have presented several statistical analysis of published research, although none covers the full range of existing thematic and methodological choices. This study seems to have established the most consistent system of categories as it has been used as a framework for other studies, as those of Kumpulainen (1991) and Rochester and Vakkari (1998).

By studying doctoral programs in library economy and Information Science, Bobinski (1986) presents data on variables such as the methodologies adopted in the dissertations in the field, the number of degrees awarded, enrollments in doctoral programs, the prestige of doctoral programs on their campus, the number of degrees awarded, and admission conditions to the program.

In 1996, to analyze the dissertations of the Graduate Program from the Information Institute of Science and Technology in Brazil, Bufrem classified the thematic and methodological designs based on the cited literature, adapting to her study the corpus of the sixteen categories proposed by Järvelin and Vakkari (1990). Powell (1985) presented a review of various research methods used by researchers in Library and Information Science (LIS) focusing, in particular, on qualitative methods.
The study of Gomes (2006) is another example of categorization using thematic and methodological choices of 63 master-degree dissertations in Information Science from the Universidade Federal de Minas Gerais from 1990 to 1999. The author points out that defining the type of study related to the categories of research, methods and strategies, techniques and research tools was the most difficult aspect when analyzing production, arguing that these aspects were also observed by Oliveira (1998). Given the difficulties, the author chose the types of studies used by Bernhard and Lambert (1993) that includes thirteen research methods in the field, as follows: content analysis; design of information systems; survey; bibliometric study; comparative study; case study; ethnographic study/naturalist survey; evaluation study/ research evaluation; experimental study; historical study/ historical research; theoretical study; Delphi method; operational research/system analysis.

Some authors advocate the importance of previously considering the categories and they suggest using previously tested models in studies of a similar nature (Allen \& Reser, 1990). For the classification system of methodologies proposed in our study, we used the methodological approach proposed by Vergara (1998).

The proposed classification system allows one to define a study according to its purpose, that is, its intention; the approach used to achieve its goal; and the focus, which shows more explicitly the strands of thought of the authors of a domain. The suggested model also provides the specification of the techniques used to collect information required for the study of the research object and the types of analysis, that is, the type of data processing.

\section{Methods}

The study is based on documentary and content analysis to identify the range of methodological choices used in the journal literature of Information Science. To apply the model and subsequent analysis that validates it, we randomly selected a corpus in the Brapci database that consisted of 689 scientific articles from 1972 to 2010. The corpus of the content analysis from the proposed categories sought to emphasize the characteristics of production in the field from the methodological choices 
of the authors and relate them to the theoretical and epistemological dimensions of the production.

The reading of abstracts and full text of the articles in the corpus was required to identify these choices, especially the part concerning the methodological approach of the authors. The assignment to the categories respected the denomination of the type of research given by the author.

We used bibliometric techniques using the Brapci platform as support for the compilation and combination of the data obtained. We also examined the prevalence of use of specific techniques in certain themes, which can reveal the trends of research in the field.

\section{Results and Discussion}

The methodological choices identified in the articles in each category: purpose, approach, focus, research techniques and types of analyses were presented as follows: in the first category, exploratory studies (378) predominated, representing a total of 54.9\% of the corpus of 689 articles, followed by descriptive studies (229), representing 33.2\% of the corpus.

The predominance of exploratory studies on the one hand reveals that research in the field investigates different themes that could contribute to the strengthening of IS, particularly regarding the contributions to new resources and Information and Communication Technology tools (ICT) that facilitate the production of innovative research in the field. On the other hand, the predominance of exploratory studies is compatible with the incipient characteristics of journal production whose theoretical and empirical constructs are still being consolidated. Exploratory studies are especially used in literature reviews in the publications over the first two decades of production analyzed, which have characteristics that do not always respect the formal language of a scientific paper, although they are recognized as such by the editors.

The characteristic of descriptive research is that it succeeds exploratory studies as it must go beyond finding, reaching a level of observation capable of portraying the conditions of a phenomenon or object, classifying and interpreting them. In Figure 1, according to annual production, we can note an increase in descriptive studies and a decrease in exploratory studies. This marks a phase of transformation in the quality of research, considering that descriptive studies provide in-depth treatment of the topics. The incidence of research regarding their purpose confirm the social science nature of IS, whose deeper studies are primarily descriptive.

We found that the methodological studies (48) are in third place, followed by assessment studies (25) and explanatory studies (9), as shown in Figure 1.

Methodological studies are even more common than assessment studies and explanatory studies in the field of Information Science, which usually address the analysis and development of methods, techniques or alternative research tools such as, for example, software development, information systems, management models or analysis methods of user profile in different contexts.

The highest incidence of assessment studies was between 1982 and 1991, with themes that refer to studies of information use, particularly in libraries, information centers and information systems. The low incidence of this type of study is due to the focus on assessment of programs and organizations with a social or operational

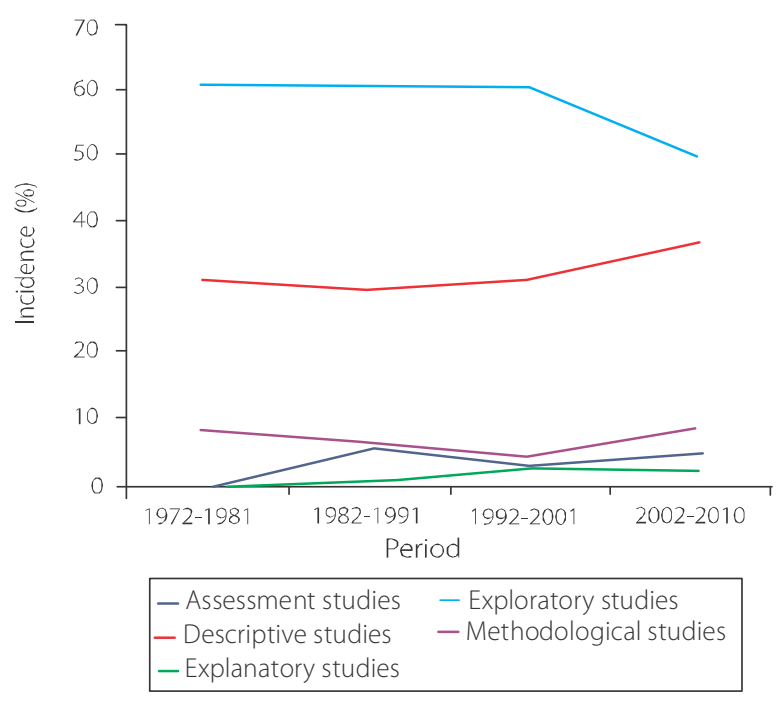

Figure 1. Types of research regarding the purposes in the corpus of the Base Referencial de Artigos de Periódicos em Ciência da Informação database per period.

Source: The authors (2012). 
nature, thus requiring caution concerning the criteria and assessment variables.

No explanatory research model appeared in the corpus in the first two decades analyzed. However, nine articles used this method between 2002 and 2010. It was found that some studies denominated as explanatory do not always go beyond the descriptive aspect, however, the authors adopted this denomination to include their studies into this category of studies due to their purpose. The aim of explanatory studies is to elucidate key factors for the occurrence of certain phenomena and the relationship established between the forces or aspects that surround them. By observing the keywords used, we noted a predominance of studies that relate and explain how flows and tools influence information dissemination and processes of management and organizational learning.

As for the research purpose of the articles analyzed, bibliographic studies (269) represent 39.50\% of the corpus, followed by documental studies (168) representing $24.67 \%$ in the same corpus. Case studies (106) rank in the third place, followed by field studies (32) and metric studies (30), as shown in Figure 2.

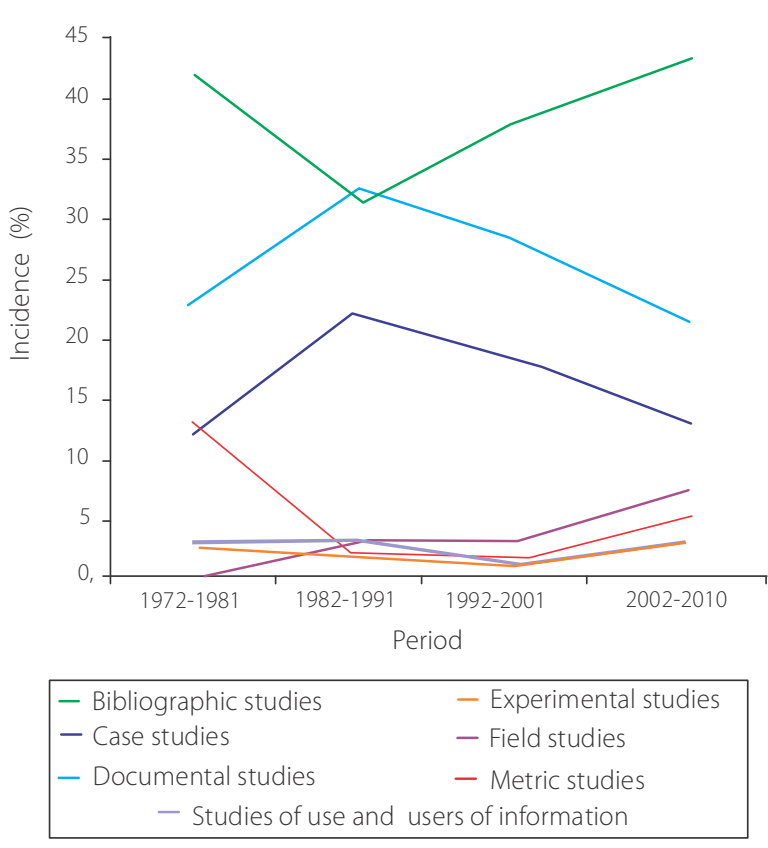

Figure 2. Types of predominant research regarding the approach in the corpus of the Base Referencial de Artigos de Periódicos em Ciência da Informação database per period.

Source: The authors (2012).
We noticed that the incidence of metric studies between 1972 and 1981 is significant and between 1982 and 1991 the production of this type of studies decreased due to the expansion of social and political studies, especially field research, documentary and case studies. The latter type of study represents $15.57 \%$ of the production analyzed. The production of field studies gradually increased over the years analyzed. These are commonly found in studies concerning social aspects, sometimes with an ethnographic focus and frequent use of systematic observation techniques and interviews, narrative techniques, discussion groups and participant observations.

It should be noted that there is no occurrence of field studies between 1972 and 1981, as during this period authors preferred an epistemological approach due to the historical moment both in politics and science, when the exercise of criticism to reality was restricted by political influence. This historical moment was marked by positivist studies that aimed at solving operational problems. Consequently, studiesfocused on the production of quantitative data, not always contextualized data, as in the case of bibliometric studies.

Case and field studies characterize the decade from 1982 to 1991, a period during which the phenomenological approach is present in studies in the field in which the use of support techniques to descriptive studies is evident. Considering the same aspects, the ways they manifest, the method is directed to the world of experience and hence it is instrumentalized with the use of questionnaires, interviews, observations and other techniques that have allowed the triangulation or combination of them with the purpose of understanding the phenomenon. These studies are also related to the hermeneutic approach, whereby information is considered a process that can be perceived and understood differently by the subjects. Information is seen from the subjects' different points of view, which is now addressed. This issue seems to clarify the incidence of studies of use and users of information, which feature a continuous line, with slight fluctuations over the 39 years analyzed, but with a tendency to increase as of 2002.

The studies of users are approximately the same as experimental studies. These, in turn, are not included in the period from 1982 to 2001. However, they 
contribute to the consolidation and development of IS as experiments often lead to laws and standards in the field. As shown in Figure 2, with some incidences of experimental studies in the 1970s, IS seeks to become a scientific field and therefore experimental studies are common during the period. In 2010, this need seems to emerge again, however, under conditions aimed at the development of production in the field in the technological context. InfoMetric studies begin to emerge in 2002, resulting from themes focused on information and communications technology and the internet. Other less representative types of studies regarding their research approach were: operational studies (9), interventionist studies (7), action studies (3) participant (2) and survey research studies (4). In view of the many options, particularly concerning research approaches, some studies may be under two different types, such as: field research and comparative research. In these cases, a predominant type is normally adopted or defined by the author, who chooses one of them.

Concerning the category on research focus, this could not be attributed to all the articles, especially the exploratory studies, given that they do not usually study a particular topic in depth nor are explicitly based on theoretical and/or epistemological frameworks of authors. Of the 689 studies, only 287 have a predominantly explicit theoretical focus, present in 176 articles (61.3\%). Theoretical research is often used as a complement in exploratory studies, characterized by discussing certain topics using philosophical, mathematical, logical theories/methodologies and others. Figure 3 shows the research focus of the studies found in the corpus and their incidence over the years.

The historical research is the second most predominant research focus, representing $17.8 \%$ of the corpus. The bibliometric focus ranks third place, primarily based on mathematical models, but the research approach is not considered a metric study because no laws are applied and they do not engage in measurement activities.

In Figure 3 we can note that the theoretical focus is the one that has increased over the years. The articles with a historical focus are more evident from 1982 to 1991 and the bibliometric focus becomes more predominant in mid-2000. The Infometric focus is more evident as of
2002, though less than the bibliometric and science metric focus. This is due to the concern with indicators on access and Internet use as well as the tools available to measure the variables related to the object. The dialectic and linguistic focuses are among the less representative research focus with three and two occurrences, respectively. The latter is related to the theme of representation and information retrieval.

The types of techniques are applied to 262 studies, considering that not all studies use them and more than one type can be identified in a single article as they can be combined. Most articles that do not use information collection techniques are exploratory studies using bibliographic research for data collection. The predominant technique is systematic observation (42), followed by questionnaire (32) and general interview (28).

The specific characteristics of systematic observation technique make it the most recurrent, being the first most frequent, representing $27.8 \%$ of the articles. This technique is structured, planned and subject to control

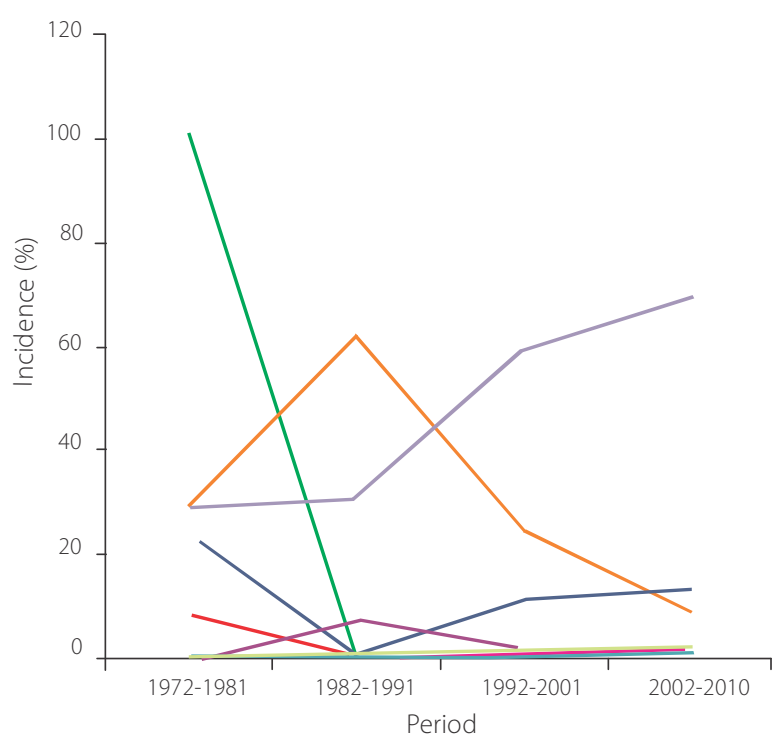

$$
\begin{array}{lll}
\hline \text { - Bibliometric } & - \text { Infometric } & \text { - Phenomenological } \\
\text { - Dialetic } & - \text { Linguistic } & - \text { Scientometric } \\
\text { - Ethnographic } & - \text { Patentometric } & - \text { Theoretical } \\
\text { - Historical } & &
\end{array}
$$

Figure 3. Research focus in the corpus of the Base Referencial de Artigos de Periódicos em Ciência da Informação database per period.

Source: The authors (2012). 
and authors have described it as a type of research, denoting intentionality as the epistemological framework of some studies, which has been increasing in recent years as a result of the phenomenological approach that influences the area of qualitative studies. Direct observation (4.2\%), on the other hand, has been used in field research. While participant observation allows greater proximity to the researcher, who is a simulated or actual subject of the group being studies, it is less significant in the corpus than the first one.

The questionnaire was the second most commonly used instrument, in particular due to its applicability in exploratory and descriptive studies in addition to being associated with the observation technique. Other characteristics such as objectivity and because that it waives the need of the interviewer make the questionnaire one of the most commonly used techniques in the studies analyzed.

The interview (28) ranks third place, representing $15.65 \%$ of the corpus. Its incidence is always less when compared to questionnaires, although its use has been increasing in field research and case studies. From 1992 to 2001 the use of questionnaires decreased and interviews became more predominant. System or program analysis or design (7) are most commonly used for creating and/or validating methods and/or types of analysis for real situations.

The technique of technological monitoring enables the monitoring of technological change and it is important for information management, particularly for companies with respect to technological vigilance. The critical incident technique was less significant, with two occurrences, but its weakness is that the researcher needs to rely on the memory of interviewee. The use of the focus group technique (3) focuses on the interaction promoted by contact and discussion among the people participating in the study. Figure 4 shows the trends of techniques used per period.

We found 367 occurrences of types of analysis, with the greatest incidence for documentary analysis (168) and content analysis (136), followed by analysis of tasks and problem solving (25) and citation analysis (16). It is worth mentioning that the analysis of context and discourse are specific types of content analysis, which

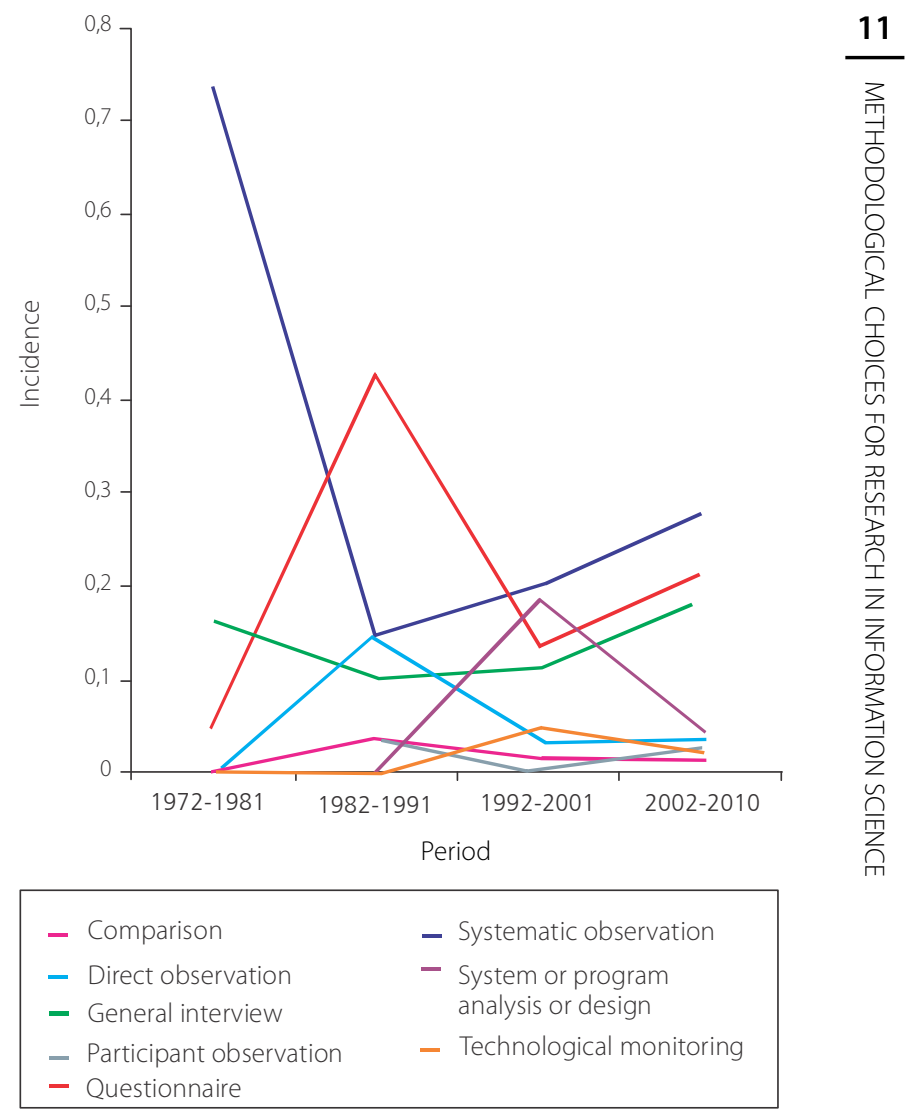

Figure 4. Types of predominant techniques in the corpus of the Base Referencial de Artigos de Periódicos em Ciência da Informação database per period.

Source: The authors (2012).

have significantly increased after 1982. In Figure 5, note the predominant types of analysis in specific time periods.

As it can be noted, the pinnacle of the use of documentanalysis is the 1980s. Soon afterwards, document analysis becomes as frequent as content analysis; later content analysis overcomes document analysis. Content analysis is also a type of document analysis, but it does not specifically analyze the document organization and representation. Since 2002, the incidence of document analysis decreases 10 percentage points when compared to content analysis.

Citation analysis, used in $4 \%$ of the corpus, is significant from 1972 to 1981. At that time, a large number of descriptive and documentary studies, characterized as citation analysis studies, were conducted. This type of analysis is common in studies on author productivity and 


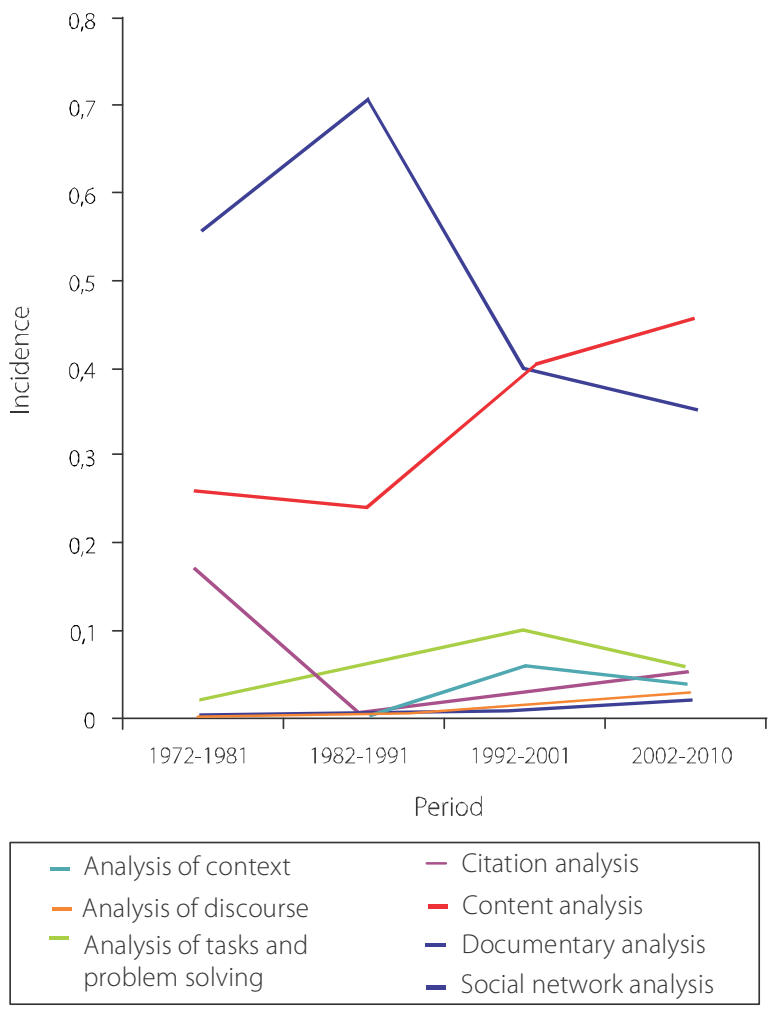

Figure 5. Types of analysis in the corpus of the Base Referencial de Artigos de Periódicos em Ciência da Informação database per period.

Source: The authors (2012)

analysis of formal sources, such as scientific journals. The type of analysis called task and problem solving (7\%) are evident from 1992 to 2001, as a characteristic analysis of management and operational studies. Social network analysis begins to be used as a type of study only as of the 1990s due to the popularity of social networking for studies on behavior, organizational environments, access and use of information.

Considering the results obtained regarding the methodological choices of authors, it was possible to presentan overview of the theoretical and epistemological influences of authors, historically determined by the circumstances of the research conditions.

\section{Conclusion}

The idea that to discern scientific knowledge from common sense knowledge, discuss themes and define scientific problems, develop and apply theories and deal with the possible methods, one has to restate the epistemology of a field and its theoretical and political dimensions.

We endeavored to show empirically through the analysis of scientific production that methodological formalism leads to stereotype situations and rigid models that delimit the fields of knowledge due to the lack of a critical attitude and creativity.

In the analysis and measurements for each type of research choice adopted, we noticed that some research studies are at an early stage of development in the field, precisely due to the predominance of exploratory studies and literature reviews, which are not always associated with analytical data processing and case studies. These studies often focus on the resolution of specific information problems in organizations and/ or institutions. A larger quantity of descriptive studies represented a positive aspect to the field because it counterbalances the exploratory studies regarding the degree of in-depth themes studied by the authors.

The diversity of nomenclatures and the lack of a common language regarding methodological choices were outstanding in the present study. Some principles for the activity of research, such as freedom of thematic and methodological choices and versatility of possible combinations of methods, techniques and tools available to the researcher, should be taken into account without affecting the choice of categories for conducting content analysis.

Finally, it is important to emphasize that the theoretical framework developed for the categories of studies does not claim to be based on a comprehensive approach of the categories proposed. The categories are intended to be a framework dedicated to rescue the intent and previous achievements to organize the methodological knowledge developed in the field.

\section{Contributors}

All authors contributed to the conception and design of the study, data analysis and final draft of the article 
References

Allen, B.; Reser, D. Content analysis in library and information science research. Library and Information Science Research v.12, n.3, p.251-262, 1990.

Bernhard, P.; Lambert, L. In search of research methods used in information science. Canadian Journal of Information and Library Science, v.18, n.3, p.1-35, 1993.

Bobinski, G.S. Doctoral programs in library and information science in the United States and Canada. Library Trends, v.34, n.4, p.687-714, 1986.

Bruyne, P.; Herman, J.; Schoutheete, M. Dinâmica da pesquisa em ciências sociais: os polos da prática metodológica. Rio de Janeiro: Francisco Alves, 1977.

Cunha, M.B. Análise de conteúdo: uma técnica de pesquisa. Revista de Biblioteconomia de Brasília, v.11, n.2, p.247-256, 1983.

Feehan, P.E. et al. Library and information science research: An analysis of the 1984 journal literature. Library and Information Science Research, v.9, n.3, p.173-185, 1987.

Freitas, J.L. Opções metodológicas em pesquisas na área de Ciência da Informação: contribuições a uma análise de domínio. 2012. Dissertação (Mestrado em Ciência, Gestão e Tecnologia da Informação) - Setor de Ciências Sociais Aplicadas, Universidade Federal do Paraná, Curitiba, 2012.

Gomes, M.Y.F.S.F. Dissertações defendidas no programa de pós-graduação em ciência da informação da UFMG, na década de 1990: um balanço. Perspectivas em Ciência da informação, v.11, n.3, p.318-334, 2006.
González de Gómez, M.N. Metodologia de pesquisa no campo da Ciência da Informação. DataGramaZero, v.1, n.6, 2000. <http://repositorio.ibict.br/bitstream/123456789/127/1/ GomesDataGramaZero2000.pdf>. Acesso em: 29 jan. 2014.

Järvelin, K.; Vakkari, P. Content analysis of research articles in Library and Information Science. Library \& Information Science Research, v.12, n.4, p.395-421, 1990.

Järvelin, K.;Vakkari, P. The evolution of library and Information Science 1965-1985: A content analysis of journal articles. Information Processing \& Management, v.29, n.1, p.129-144, 1993.

Kumpulainen, S. Library and information science research in 1975: Content analysis of the journal articles. Libri, v.41, n.1, p.59-76, 1991.

Lloyd, C. As estruturas da história. Rio de Janeiro: Zahar, 1995.

Oliveira, P.S. (Org.). Metodologia das ciências humanas. São Paulo: Hucitec, 1998.

Powell, R.R. Basic research methods for librarians. Norwood: Ablex, 1985. (Libraries and Information Science Series).

Rochester, M.; Vakkari, P. International LIS research: A comparison of national trends. IFLA Journal, v.24, n.3, p.166175, 1998

Vergara, S.C. Projetos erelatórios de pesquisa em administração. 3.ed. São Paulo: Atlas, 1998. 

